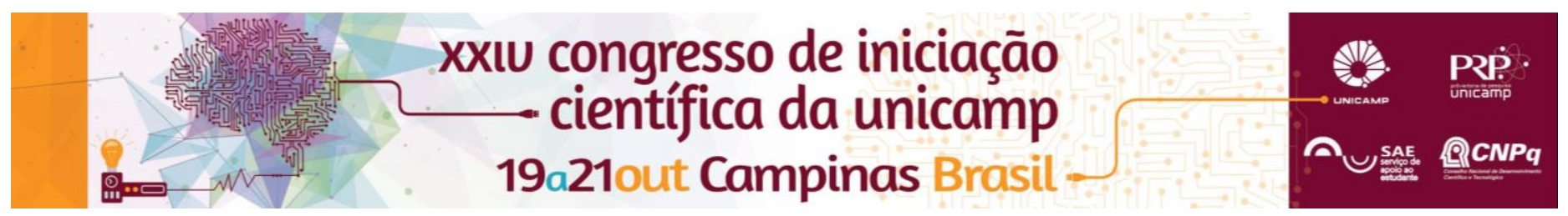

\title{
POTENCIALIDADES DA INTERMODALIDADE: uma avaliação da logística de exportação da soja brasileira.
}

\author{
Monique Filassi` Orientador: Profa. Dra. Andrea Leda Ramos Oliveira
}

\begin{abstract}
Resumo
As questões relacionadas à logística apresentam-se como um gargalo interferindo diretamente na capacidade de crescimento das exportações da soja. Isto posto, a presente pesquisa tem como objetivo evidenciar os principais projetos de infraestrutura conduzidos pelo Estado que promovam a prática da intermodalidade, beneficiando o escoamento dessa oleaginosa por meio de novos corredores de exportação.
\end{abstract}

\section{Palavras-chave:}

Logística, Transporte, Agronegócio.

\section{Introdução}

A cultura da soja é responsável por $49 \%$ da área plantada com grãos no Brasil e firmou-se como um dos produtos impulsionadores da balança comercial do país (MAPA, 2016).

Entretanto, gargalos como fragilidades logísticas na estocagem e transporte desses grãos diminuem a competitividade desse setor. Usualmente, aponta-se a predominância do modal rodoviário na matriz de transportes brasileira como a principal fonte de ineficiência e de redução de lucratividade dos produtores agrícolas (OLIVEIRA, 2011).

Nos últimos anos cresceu a utilização de mais de um modal para o transporte de mercadorias, pois além dos ganhos econômicos que essa atividade proporciona, o crescimento das exportações tem contribuído para essa mudança (BALLOU, 2010).

\section{Resultados e Discussão}

Esse trabalho tem como base a pesquisa exploratória através de levantamentos bibliográficos e dados estatísticos obtidos por órgãos governamentais.

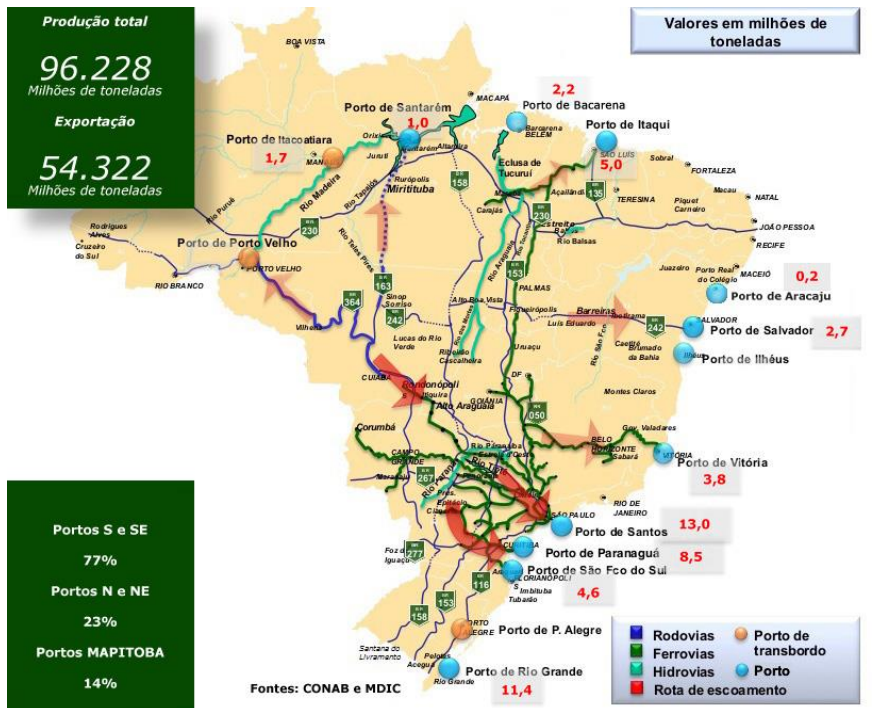

Figura 1. Mapeamento dos Principais Corredores de Exportação de Soja (Safra 14/15). Fonte: BNDES (2014) apud Nelson Siffert (2014). Adaptado pelo autor.

O aumento da quantidade de soja exportada pelos portos das regiões Norte e Nordeste ocorreu devido a finalização de importantes obras que melhoraram antigas rotas intermodais de escoamento e deram início a novas, são elas:

- Rota 1: Ferrovia Norte-Sul, liga regiões produtoras do Centro-Oeste ao Norte, através do trecho Ouro Verde/Anápolis (GO) passando por Palmas (TO), seguindo até Açailândia (MA) onde tem-se a opção de continuar o trajeto pela Estrada de Ferro Carajás até o Porto de Itaqui (MA) ou pela Hidrovia Tocantins/Araguaia até o Porto de Barcarena (PA).

- Rota 2: Rodovia BR-163/PA, liga regiões produtoras do Centro-Oeste com o Norte, a construção do trecho divisa MT/PA - Santarém dessa rodovia e a Rodovia BR-230/PA através da construção do trecho divisa TO/PA - Rurópolis, que dá acesso a Miritituba, possibilitam que a carga seja transportada do Terminal de Miritituba (PA), seguindo a Hidrovia Tapajós/Teles até Porto de Santarém ou Porto de Barcarena (PA).

- Rota 3: Hidrovia do Madeira, liga regiões produtoras do Centro-Oeste ao Norte, a dragagem, recuperação de sinalização dessa hidrovia contribuem para que cargas vindas pela BR-364 MT/RO cheguem até o Porto de Itacoatiara (AM) ou Porto de Santarém (PA).

O comportamento dos fretes varia em relação aos corredores de exportação da soja. MAPITOBA-São Luís possui a vantagem competitiva de ter o menor índice em comparação aos demais corredores (ESALQ-LOG, 2016).

\section{Conclusões}

A intermodalidade visa eliminar gargalos logísticos com intuito de obter ganhos econômicos. A formação das novas rotas intermodais 1, 2 e 3 propiciou o aumento da utilização de corredores de exportação com menores índices de fretes como MAPITOBA-São Luís.

BALLOU, Ronald H. Gerenciamento da Cadeia de Suprimentos/Logística Empresarial; tradução Raul Rubenich. 5 ed. Porto Alegre: Bookman Editora, 2010, p.149-158.

ESALQ-LOG. Grupo de Pesquisa e Extensão em Logística Agroindustrial. Sistema de Informações de Fretes - SIFRECA. Boletim Sifreca Soja. Disponível em: <http://esalqlog.esalq.usp.br/sifreca/soja-marco2016-no-19/>. Acesso em: Mai. 2016.

MAPA. Ministério da Agricultura, Pecuária e Abastecimento. Soja. Disponível em: $<$ http://www.agricultura.gov.br/>. Acesso em: Abr. 2016.

OLIVEIRA, A. L. R. O sistema logístico e os impactos da segregação dos grãos diferenciados: desafios para o agronegócio brasileiro. 2011.

SIFFERT, N. Infraestrutura e Construção. Apoio de BNDES à Infraestrutura. Disponível em: $<\mathrm{http}: / /$ pt.slideshare.net/fgv-oficial/nelson-siffert $>$. Acesso em: Mai. 2016. 